\title{
Nitric Oxide Is an Essential Negative Regulator of Cell Proliferation in Xenopus Brain
}

\author{
Natalia Peunova, Vladimir Scheinker, Hollis Cline, and Grigori Enikolopov \\ Cold Spring Harbor Laboratory, Cold Spring Harbor, New York 11724
}

\begin{abstract}
Mechanisms controlling the transition of a neural precursor cell from proliferation to differentiation during brain development determine the distinct anatomical features of the brain. Nitric oxide (NO) may mediate such a transition, because it can suppress DNA synthesis and cell proliferation. We cloned the gene encoding the neuronal isoform of Xenopus NO synthase (XNOS) and found that in the developing brain of Xenopus tadpoles, a zone of XNOS-expressing cells lies adjacent to the zone of dividing neuronal precursors. Exogenous NO, supplied to the tadpole brain in vivo, decreased the number of prolifer-
\end{abstract}

The regulation of progression from proliferation to differentiation in the population of precursor cells has direct bearing on the formation of a functional nervous system (Jacobson, 1991; Kandel et al., 2000). The signaling systems involved in regulating cell division during brain morphogenesis are only beginning to be understood. Accumulating evidence suggests that nitric oxide (NO), a versatile diff usable signaling molecule (Ignarro and $\mathrm{Mu}-$ rad, 1995), may contribute to controlling the transition from cell proliferation to differentiation. NO added to cultured cells suppresses DNA synthesis and prevents cell proliferation (Garg and Hassid, 1989). In several types of cultured cells, NO, endogenously produced in response to growth factors can act as a permissive factor to restrict cell cycle progression and to promote differentiation (for review, see Enikolopov et al., 1999). In Drosophila, $\mathrm{NO}$ affects cell proliferation and differentiation in developing imaginal disks of the larvae and in the embryo (Kuzin et al., 1996; Wingrove and O'Farrell, 1999; Kuzin et al., 2000), and in moth, NO mediates ecdysteroid-controlled cell division in the optic lobe (Champlin and Truman, 2000).

Several lines of evidence suggest that NO may also control neurogenesis in the vertebrate brain. NO is produced abundantly in developing brain by NO synthases (NOSs). The spatiotemporal pattern of NOS expression is compatible with the possibility that NO is an antiproliferative agent. For instance, in the developing

Received June 6, 2001; revised Aug. 10, 2001; accepted Aug. 28, 2001.

This work was supported by grants from the National Science Foundation (N.P. and H.C.), National Institutes of Health (G.E. and H.C.), Klingenstein Foundation, Seraph Foundation, and Charles Henry Leach II Foundation (G.E.). We are grateful to Dr. M. W. King for the gift of the cDNA library used for the isolation of XNOS-cloned cDNA. We thank Nadeem Ali (Cambridge University, Cambridge, UK) and Christy Mannino (State University of New York, Binghampton, NY), who joined our teams during their work in the summer Cold Spring Harbor Laboratory Undergraduate Research Program. We thank Kim Bronson for excellent assistance in the experiments, Yuri Stasiv for help in the cloning of XNOS, and Tim Tully for help with the statistical analysis of the data. We are grateful to Julian Banerji for invaluable advice and critical reading of this manuscript.

Correspondence should be addressed to Dr. Natalia Peunova, Cold Spring Harbor Laboratory, 1 Bungtown Road, P.O. Box 100, Cold Spring Harbor, NY 11724. E-mail: peunova@cshl.org.

Copyright (C) 2001 Society for Neuroscience $\quad 0270-6474 / 01 / 218809-10 \$ 15.00 / 0$ ating cells and the total number of cells in the optic tectum. Conversely, inhibition of NOS activity in vivo increased the number of proliferating cells and the total number of cells in the optic tectum. NOS inhibition yielded larger brains with grossly perturbed organization. Our results indicate that NO is an essential negative regulator of neuronal precursor proliferation during vertebrate brain development.

Key words: nitric oxide; Xenopus; differentiation; proliferation; brain; optic tectum; neuron; neuronal precursors

rodent brain, transient elevation of NOS expression correlates with the cessation of division of committed precursor cells and the beginning of their differentiation (Bredt and Snyder, 1994a; Blottner et al., 1995). In the adult mouse brain, NOS-positive neurons lie adjacent to but not within the areas of neurogenesis (Moreno-Lopez et al., 2000). Although these observations are consistent with the notion that $\mathrm{NO}$ has antiproliferative activity in the brain, the true role that $\mathrm{NO}$ plays in controlling brain morphogenesis remains an open question.

Xenopus laevis represents a convenient vertebrate system in which to study the role of NO in CNS development. Division of neural precursors, their differentiation, and synaptogenesis occur in a spatially distinct pattern throughout development of the tadpole (Straznicky and Gaze, 1972; Lazar, 1973). For instance, in the optic tectum, new cells are generated in the narrow germinal zone at the caudomedial border of the tectum and are displaced laterally and rostrally from the germinal zone as they differentiate and mature. Consequently, interference with the normal course of cell proliferation would be recognized as a disruption in the spatiotemporal pattern of development in the midbrain.

To examine the role of $\mathrm{NO}$ in brain morphogenesis, we cloned the Xenopus NOS gene (XNOS) and determined the developmental pattern of its expression. We then tested the effects of manipulating NO levels on the developing brain of the tadpole. We report that XNOS-positive cells lie adjacent to the germinal zone in the tectum. In addition, we found that exogenous NO decreases, whereas suppression of NOS activity increases, the number of proliferating cells and the total number of cells in the brain. These reciprocal effects of the gain and loss of NO on cell proliferation support a model in which NO acts as a negative regulator of cell proliferation in the intact vertebrate brain.

\section{MATERIALS AND METHODS}

Animals, NOS inhibitors, and NO donors. Albino X. laevis tadpoles were obtained by human chorionic gonadotropin-induced matings and raised under standard conditions. At stage 45 (Nieuwkoop and Faber, 1994), animals were anesthetized in $0.02 \% 3$-aminobenzoic acid (Sigma, St. 
Louis, MO), and a tiny piece $(10 \times 10 \times 30 \mu \mathrm{m})$ of slow release Elvax plastic polymer (DuPont, Billerica, MA) was inserted into the tectal ventricle through an incision made in the overlying skin with a 30 gauge needle. Elvax was prepared as described previously (Cline et al., 1987) with stock concentrations of the NOS inhibitors 2-ethyl-2-thiopseudourea (ETU; Sigma) and L-nitro-arginine methyl ester (L-NAME; Sigma), the inactive enantiomer D-NAME (Sigma), or the NO donor $S$-nitrosoacetylpenicillamin (SNAP; Sigma) prepared as a 1:10 ratio of chemical to polymer matrix. Control animals were treated with Elvax impregnated with saline ( $0.1 \mathrm{M}$ phosphate buffer). The slow release characteristics of Elvax have been documented for a variety of molecules in several experimental systems (Cline et al., 1987; Cline and Constantine-Paton, 1989; Schlaggar et al., 1993; Renteria and Constantine-Paton, 1999). Low molecular weight molecules, including L-NAME, are released at a constant rate for up to $30 \mathrm{~d}$ (Cline et al., 1987; Renteria and ConstantinePaton, 1999). Quantitative evaluation or bioassays of relative concentrations of released chemicals demonstrated that $\sim 1 \%$ of the stock concentration of drug is released from the Elvax polymer per day (Cline and Constantine-Paton, 1989; Schlaggar et al., 1993). Thus, stock concentrations used to prepare the plastic (1 M L-NAME, $1 \mathrm{M}$ D-NAME, 10 mM ETU, and $300 \mathrm{~mm}$ SNAP) likely reflect $\sim 10 \mathrm{~mm} \mathrm{L-NAME}$ and D-NAME, $0.1 \mathrm{~mm}$ ETU, and $3 \mathrm{~mm}$ SNAP released from the Elvax into the brain ventricle (also see Renteria and Constantine-Paton, 1999). It is important to note that drugs are further diluted in the CSF in the ventricle. In separate experiments, animals exposed to even higher concentrations of these compounds did not display any apparent signs of toxicity. The high specificity of the L-NAME and ETU toward NO synthases has been extensively documented (for review, see Stamler and Feelisch, 1996). These inhibitors each act on mammalian neuronal NOS (nNOS), endothelial NOS, and inducible NOS with similar $K_{\mathrm{i}}$ values (Stamler and Feelisch, 1996). We determined that $>80 \%$ of NOS activity was inhibited in brain extracts prepared from animals implanted with $1 \mathrm{M}$ L-NAME Elvax but not in extracts from animals implanted with $1 \mathrm{M}$ D-NAME Elvax (also see Renteria and Constantine-Paton, 1999).

cDNA library, PCR, XNOS isolation, and sequence analysis. A short 150 bp DNA fragment was generated by PCR using Xenopus genomic DNA and degenerative primers to the conservative portion of exon 12 of rat neuronal NOS. This fragment was used as a probe to screen the stage 42 Xenopus tadpole cDNA library kindly provided by Dr. M. W. King (Indiana University School of Medicine). Sequencing of cDNA clones demonstrated that the largest open reading frame (XNOS) codes for a protein of 1419 amino acids with $79 \%$ identity and $85 \%$ similarity to rat neuronal NOS. Enzymatic activity of XNOS after transfection into 293 cells was determined as described previously (Stamler and Feelisch, 1996). The details of XNOS cloning and analysis will be described elsewhere (V. Scheinker, N. Peunova, and G. Enikolopov, unpublished procedures).

Histochemistry, antibodies, and in situ hybridization. The $1500 \mathrm{bp}$ fragment of XNOS was cloned into a pBluescript II $\mathrm{KS}^{+}$vector. A digoxigenin-UTP-labeled probe for in situ hybridization was prepared using T3 RNA polymerase, and in situ hybridization with the wholemount preparations of the Xenopus tadpole brain was performed as described previously (Hemmati-Brivanlou et al., 1990).

Immunocytochemistry with whole-mount preparations and sections of the tadpole was performed as described previously (Harlow and Lane, 1990). Monoclonal antibodies to neuron-specific type-II $\beta$-tubulin (Ntubulin), N-CAM (developed by U. Rutishauser, Memorial SloanKettering Cancer Center, New York, NY), and Islet-1 (developed by T. M. Jessell, Columbia University, New York, NY) were obtained from the Developmental Studies Hybridoma Bank developed under the auspices of the National Institute of Child Health and Human Development and maintained by The University of Iowa Department of Biological Sciences (Iowa City, IA). An anti-mouse antibody conjugated to fluorescein (Roche Molecular Biochemicals, Indianapolis, IN) was used as a secondary antibody. Specimens were visualized and photographed under fluorescence or Nomarski optics on a Zeiss (Thornwood, NY) Axiophot fluorescent microscope. Antibodies to XNOS were R20 polyclonal antibodies to rat neuronal NOS (Santa Cruz Biotechnology, Santa Cruz, CA). These antibodies were raised against a 20 -amino acid (aa)-long nNOSspecific peptide, which is identical in rat nNOS (position 1400-1419) and Xenopus XNOS (position 1390-1409). They recognized a specific band in extracts from the rat and Xenopus brains and cloned rat nNOS and XNOS cDNA expressed in cultured cells and analyzed by Western blotting.

For nuclei visualization, brain sections were stained with $4^{\prime}, 6-$ diamidino-2-phenylindole (DAPI), a fluorescent DNA stain (Molecular Probes, Eugene, OR), at $1 \mu \mathrm{M}$. To identify cells in S phase, tadpoles were injected with $50 \mu \mathrm{g} / \mathrm{ml}$ 5-bromo-deoxyuridine (BrdU; Becton Dickinson, Mountain View, CA). After $2 \mathrm{hr}$ of survival, animals were fixed in $3.7 \%$ paraformaldehyde for $2 \mathrm{hr}$ and then in $70 \%$ ethanol overnight. BrdUlabeled $\mathrm{S}$ phase nuclei were visualized after denaturating DNA in $2 \mathrm{~N}$ $\mathrm{HCl}$ and $0.5 \%$ Triton $\mathrm{X}-100$ for $2 \mathrm{hr}$ and incubation with fluoresceinconjugated antibodies to BrdU (Becton Dickinson), as suggested by the manufacturer. Analysis of apoptosis during tadpole brain development was performed on $20 \mu \mathrm{m}$ brain sections by terminal deoxynucleotidyl transferase-mediated biotinylated UTP nick end-labeling (TUNEL) assay (Roche Molecular Biochemicals) as suggested by the manufacturer. Samples were analyzed on a Zeiss Axiophot fluorescent microscope and a Noran Instruments (Middleton, WI) confocal microscope.

Cell count and volume measurement. Horizontal $20 \mu \mathrm{m}$ sections of the control and treated animals were collected for cell counting. Each group contained three to five animals. Three sequential matching dorsal $20 \mu \mathrm{m}$ sections, representing most of optic tectum, of each animal were collected and used to determine the volume, cell number, cell density, and number of BrdU- and TUNEL-positive cells. Thus, each number presented for the comparison in Tables 1-3 is a result of the measurements conducted on 9-15 sections, which minimized the possible error associated with the variability in brain sectioning between animals.

To determine the surface of the cell body area, borders of the cell body region of the midbrain were drawn over the projection of each section of the series at a magnification of $10 \times$, and the surface area was determined by superimposing a point-counting grid. The thickness of the section was determined by $Z$-micrometer after staining. The volume of the section was calculated by multiplying the area by the thickness. The total number of cells was determined using the optical disector method (Coggeshall, 1992). In each section of the series, the total number of DAPI-stained nuclei were counted within $40 \times 40 \times 5 \mu \mathrm{m}$ sampling boxes selected randomly throughout the area. Cells that were intersected by the sampling frame and cells in the lower-most focal plane were excluded from counting. Average counts calculated from sampling boxes were extrapolated for the entire volume of the cell body area of the section. The number of BrdU- and TUNEL-labeled cells was determined throughout the entire section. To avoid oversampling and undersampling because of the size and shape difference, the size of DAPI stained nuclei in the midbrain area was determined for both coronal and horizontal sections of animals exposed to Elvax with L-NAME, D-NAME, ETU, or saline. No statistically significant differences in the area size of the nuclei were found between the sections in all of the pairwise comparisons (in all cases $p>0.2$ ); thus, no stereological corrections for sampling errors were applied. Data for three sections were combined to represent the volume and the cell number of each brain.

\section{RESULTS}

\section{Cloning and distribution of NOS in Xenopus}

We cloned NOS cDNA from a Xenopus tadpole stage 42 cDNA library using highly conserved regions from mammalian and Drosophila NOS genes as probes. The nucleotide and deduced amino acid sequences of the cloned XNOS gene show the highest similarity to the neuronal isoform of NOS (nNOS or NOS1) of mammals (Fig. 1a). The deduced XNOS protein contains the determinants that are crucial for NOS activity, including regions for binding flavin mononucleotide, flavin-adenine dinucleotide, NADPH, tetrahydrobiopterin (BH4), heme, and calmodulin and a consensus site for phosphorylation by cAMP-dependent PKA (Bredt and Snyder, 1994b; Nathan and Xie, 1994; Wang and Marsden, 1995). The N terminus of XNOS contains a PDZ motif, which is crucial for association with PDZ domains of other proteins, such as PSD-95, $\alpha 1$-synthrophin (Brenman et al., 1995), and CAPON (Jaffrey et al., 1998). When expressed in cultured cells, XNOS cDNA produced a polypeptide of the expected size of 160 $\mathrm{kDa}$, similar to mammalian neuronal NOS and NOS from the frog brain (Fig. 1b). XNOS generated NO with high efficiency after transfection into cultured cells (Fig. 1c). Production of NO was dependent on the presence of calcium, BH4, and NADPH, and was 
a
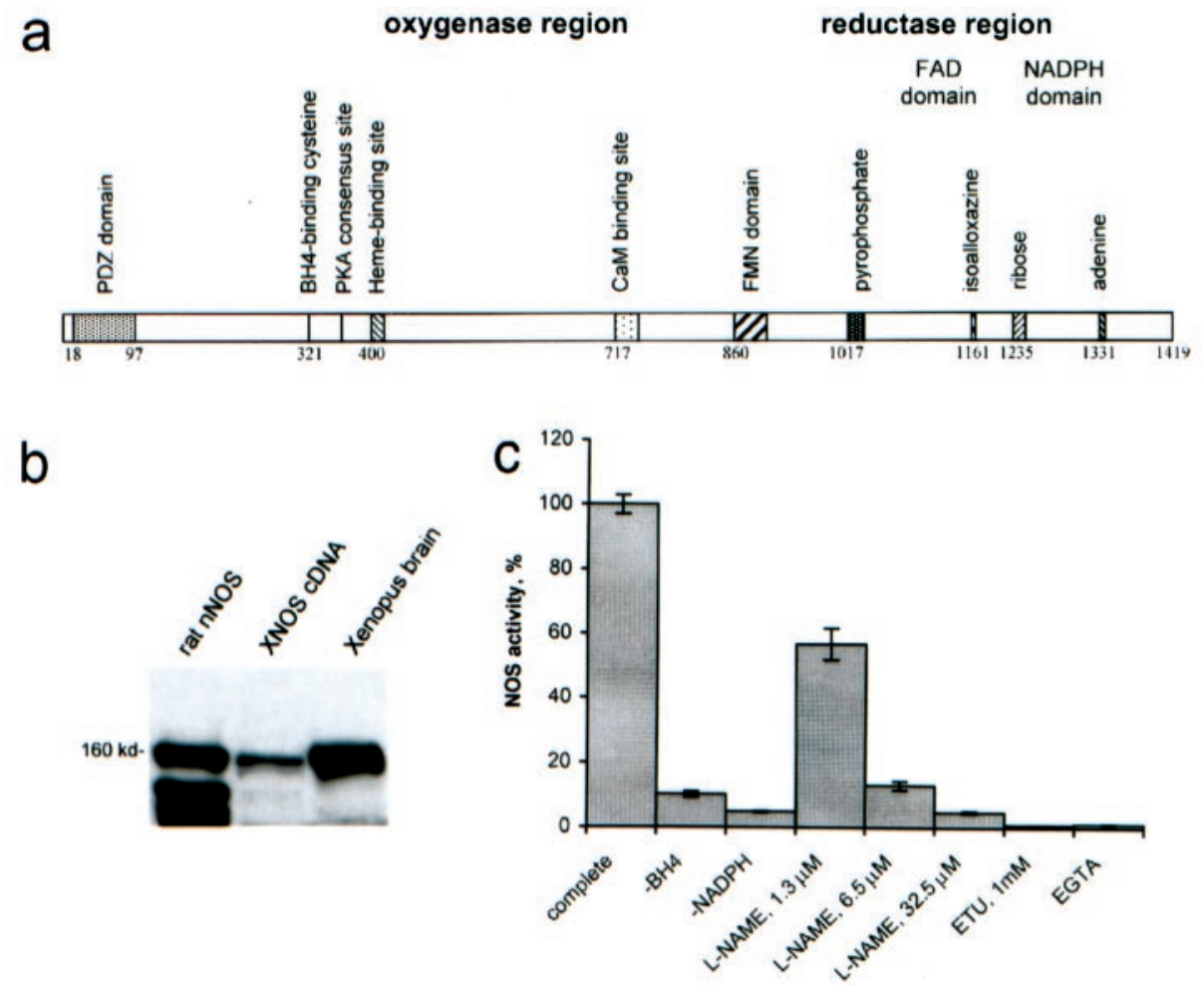

e

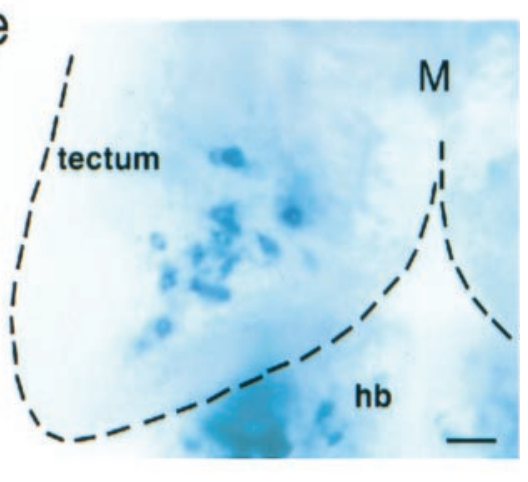

Figure 1. Structure and expression of XNOS. $a$, Structure of XNOS cDNA. cDNA $(6.5 \mathrm{~kb})$ was cloned from a stage 42 Xenopus cDNA library. It corresponds to a protein of 1419 aa, which has all of the regions of neuronal NOS isoforms conserved between mammals and Drosophila. FAD, Flavin-adenine dinucleotide; $F M N$, flavin mononucleotide. $b$, Expression of XNOS. Western blots of protein extracts were probed using a rat nNOS- and XNOS-specific polyclonal antibody. Each lane was loaded with $25 \mu \mathrm{g}$ of protein isolated from 293 cells transfected with rat nNOS cDNA (first lane), 293 cells transfected with XNOS cDNA (second lane), and adult Xenopus frog brain (third lane). The blot was treated with R20 polyclonal antibody raised against a 20 aa peptide, which is identical in both rat nNOS (positions 1400-1419) and Xenopus XNOS (positions 1390-1409). $c$, Enzymatic activity of recombinant XNOS. 293 cells were transfected with XNOS cDNA, and the NOS activity in the cell extract was measured using the arginine-to-citrulline conversion assay in the presence or absence of various cofactors and inhibitors. $d$, In situ hybridization of XNOS RNA probe in whole-mount stage 47 tadpole brain and eyes. ret, Retina; telen, telencephalon; tectum, optic tectum; $m b$, midbrain; $h b$, hindbrain; $R$, rostral; $C$, caudal. $e$, Whole-mount NADPH-diaphorase staining of the tadpole brain at stage 46 . The region depicted corresponds to the central left portion of $d$. Light staining illustrates NADPH-diaphorase-positive cell bodies in the caudal optic tectum. Note that their position is similar to that of XNOS-positive cells in $d$. The cluster at the bottom corresponds to the XNOS-positive cells of the hindbrain in $d$. The dotted line marks the optic tectum; $M$, midline. Scale bars: $d, 100 \mu \mathrm{m}$; $e, 25 \mu \mathrm{m}$. completely blocked by application of the specific inhibitors of NOS L-NAME and ETU.

In situ hybridization using the XNOS probe shows that XNOS RNA is present in cell bodies located in a distinct pattern in the optic tectum, telencephalon, hindbrain, and retina of the tadpole (Fig. 1d). A similar pattern is seen after histochemical NADPH-diaphorase staining for NOS activity (Fig. 1e), suggesting that XNOS-positive cells account for the majority of the diaphorase-positive cells in the optic tectum. Together, the gene structure, enzymatic properties, and distribution of XNOS indicate that we have cloned the ortholog of the mammalian neuronal isoform of NOS.

Differentiation of tadpole brain tissue is accompanied by the continuous generation of new neurons in a narrow germinal zone at the caudomedial edge of the optic tectum (Straznicky and Gaze, 1972). If NO triggers the transition from proliferation to differentiation, one might expect a source of NO to be adjacent to the germinal zone of the tectum where cells undergo this transition. To determine the relative positions of proliferating cells and NOS-expressing cells in animals from stages $43-50$, cells in $\mathrm{S}$ phase were labeled with BrdU, and NOS-positive cells were identified by in situ hybridization with XNOS RNA. BrdUpositive cells occupy a narrow crescent-shaped proliferative zone in the caudal and caudomedial regions of the optic tectum at all stages examined (Fig. 2a,d). A narrow band of XNOS-positive cells was found to lie adjacent to the proliferative zone of the optic tectum (Fig. 2b,e). As in the optic tectum, XNOS-positive cells in the telencephalon and hindbrain lie adjacent to proliferative zones. Sagittal views of the brains reveal two clusters of XNOS-positive cells in the midbrain, one located dorsally in the optic tectum, and a second located ventrally in the floor of the midbrain (Fig. 2c,f). The dorsal cluster of XNOS-positive cells lies adjacent to the optic tectum proliferative zone. The juxtaposition of the BrdU- and the XNOS-positive cells is most clearly seen in Figure $2 g-k$, which are double-labeled for XNOS and BrdU. It is interesting to note that the XNOS- and BrdU-positive cells remain adjacent throughout this developmental period up to stage 50, the latest stage examined, despite the continuous cell proliferation and increase in brain size during this time. This suggests that XNOS expression in these cells adjacent to the 
Figure 2. Complementary patterns of NOS expression and BrdU incorporation in the developing Xenopus brain. Wholemount brains from stage $43(a-c, g)$ and $47(d-f, h)$ tadpoles are shown labeled for $\operatorname{BrdU}(a, d, g, h)$ after $2 \mathrm{hr}$ of survival and by in situ hybridization for XNOS $(b, c$, $e-h)$. Dorsal views of brains $(a, b, d, e)$ from different animals are aligned to show the relative position of BrdU- and XNOS-positive cells in brains of comparable stages. XNOS-positive cells are located in the telencephalon, midbrain, and hindbrain, neighboring but not overlapping sites of BrdU incorporation. Sagittal views of whole-mount brains $(c, f)$ show the dorsoventral distribution of XNOSpositive cells. Two clusters of XNOSpositive cells are located in the caudal midbrain. One cluster lies in the caudal optic tectum on the roof of the midbrain near the tectal proliferative zone, and a second cluster is in the ventral midbrain. Whole-mount preparations, viewed sagitally $(g, h)$, and horizontal sections $(i-k)$ of the optic tectum were double-labeled for BrdU and XNOS expression by in situ hybridization. The dorsal cluster of XNOS-positive cells in the optic tectum ( $g-k$, black arrows) lies adjacent to BrdU-positive cells in the proliferative zone ( $g-k$, white arrows) at stages 43 and 47. The optic tectum is located on the dorsal aspect of the caudal midbrain, as shown in $c$ and $f$. telen, Telencephalon; $m b$, midbrain; $h b$, hindbrain; $R$, rostral; $C$, caudal; $D$, dorsal; $V$, ventral. In $i-k$, rostral is at the top. Scale bar, $50 \mu \mathrm{m}$.
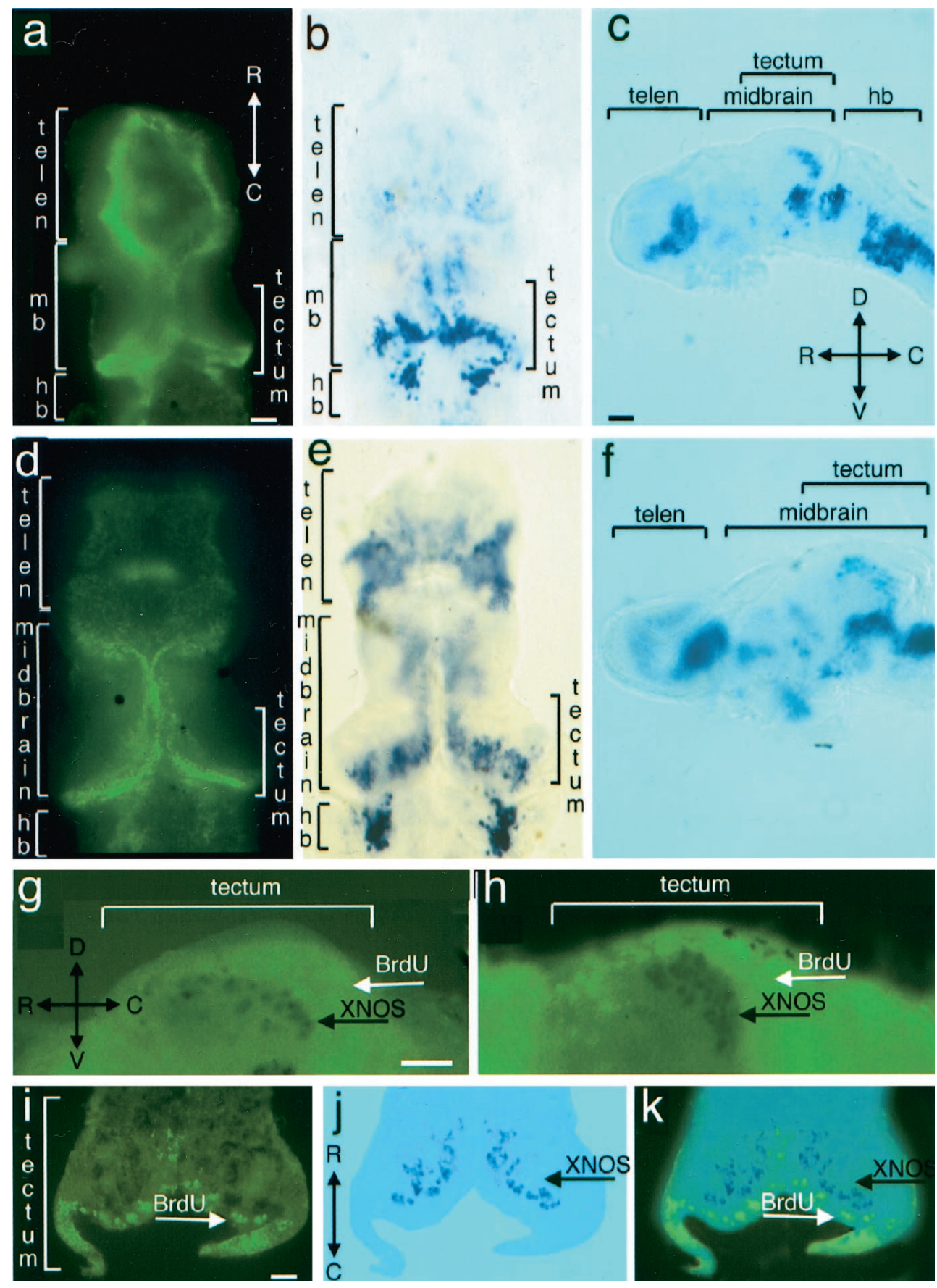

proliferative zone is likely to be transient. The critical observation from these experiments is that although the germinal zone itself is free of NOS, it is closely apposed to cell bodies of NOSexpressing cells. This distribution may reflect a functional role of NO as a signal to these newly dividing cells.

\section{NO donors decrease cell proliferation}

To test the effect of exogenously supplying NO to the developing tadpole brain, we inserted into the brain ventricle of stage 45 tadpoles pieces of the slow release matrix Elvax impregnated with SNAP, a widely used donor of NO, which releases NO during hydrolysis. Control animals were implanted with Elvax prepared with saline. One and 3 d later, animals were injected with BrdU for $2 \mathrm{hr}$, followed by fixation. Horizontal sections of the midbrain containing the optic tectum were analyzed for the following parameters: the total number of cells (as measured by the number of DAPI-stained nuclei), the number of proliferating cells (as measured by BrdU incorporation), the number of apoptotic cells (as measured by TUNEL assay), the relative numbers of BrdUand TUNEL-positive cells per $10^{3}$ total cells (BrdU and TUNEL indices), the volume, and the cell density (Fig. 3, Table 1).

Exogenously supplied NO drastically decreases the number of proliferating cells and the BrdU index in the midbrain at day 1 to $\sim 5 \%$ of the control values (Fig. 3, Table 1). By $3 \mathrm{~d}$, the effect of SNAP on cell proliferation in the midbrain was not significantly different from controls, likely reflecting the extensive hydrolysis of the NO donor and decreased NO release from the Elvax. It is important to note that the resumption of normal rates of cell 


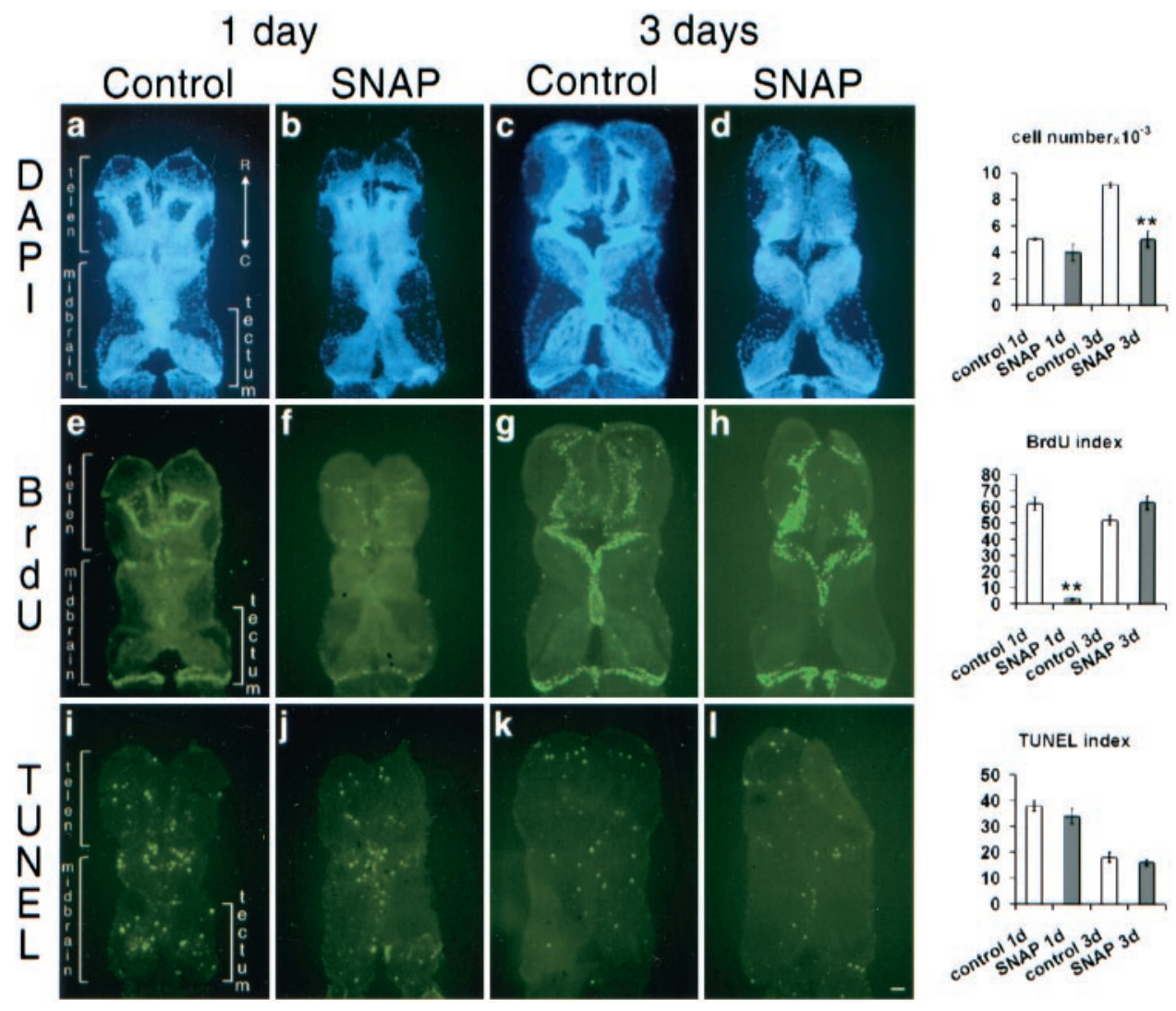

Figure 3. Increased levels of NO decrease cell proliferation in the developing brain. Animals were treated for 1 or $3 \mathrm{~d}$ with saline solution (Control) or NO donor SNAP. Sequential horizontal brain sections were stained with DAPI to stain nuclei $(a-$ $d)$, with BrdU antibodies to label proliferating cells $(e-h)$, and with TUNEL to label apoptotic cells $(i-l)$. Rostral $(R)$ is at the top; $C$, caudal. The brain regions telencephalon (telen), midbrain, and optic tectum are marked on the left; marking applies to all images. One day of exposure to the NO donor SNAP decreases BrdU incorporation in proliferative zones throughout the brain without causing any apparent change in apoptosis. By $3 \mathrm{~d}$, BrdU incorporation into experimental and control brains appears comparable likely because of hydrolysis of SNAP. The histograms on the right depict quantitative changes induced by SNAP, which are presented in more detail in Table 1. ${ }^{* *} p<0.01$. Scale bar, $50 \mu \mathrm{m}$.

Table 1. NO donor SNAP decreases cell number, brain volume, and cell density in the tadpole brain

\begin{tabular}{|c|c|c|c|c|c|c|}
\hline & Control, $1 \mathrm{~d}$ & SNAP, $1 \mathrm{~d}$ & $\begin{array}{l}\text { Change } \\
\text { (\% of control) }\end{array}$ & Control, $3 \mathrm{~d}$ & SNAP, $3 \mathrm{~d}$ & $\begin{array}{l}\text { Change } \\
\text { (\% of control) }\end{array}$ \\
\hline Cell number & $5020 \pm 82$ & $3983 \pm 606$ & 79.3 & $9125 \pm 194$ & $5012 \pm 594 * *$ & 54.9 \\
\hline Brain volume $\left(\mathrm{mm}^{3} \times 10^{-4}\right)$ & $78.4 \pm 4.8$ & $66.2 \pm 6.4$ & 84.4 & $116.5 \pm 6.2$ & $80.1 \pm 8.6^{*}$ & 68.8 \\
\hline Cell density $\left(\right.$ cells $\left./ \mathrm{mm}^{3} \times 10^{-4}\right)$ & $64 \pm 5$ & $60 \pm 14$ & 93.8 & $78 \pm 3$ & $63 \pm 2$ & 80.1 \\
\hline BrdU-positive cells (total) & $310 \pm 83$ & $12 \pm 1^{* *}$ & 3.9 & $473 \pm 7$ & $315 \pm 6^{* *}$ & 66.6 \\
\hline \multicolumn{7}{|l|}{ BrdU-positive cells $/ 10^{3}$ cells } \\
\hline (BrdU index) & $62 \pm 4$ & $3 \pm 0.5^{* *}$ & 4.8 & $52 \pm 5$ & $63 \pm 6^{* *}$ & 121.0 \\
\hline TUNEL-positive cells (total) & $190 \pm 3.5$ & $132 \pm 10^{* *}$ & 69.4 & $163 \pm 15$ & $80 \pm 10^{* *}$ & 49.1 \\
\hline \multicolumn{7}{|l|}{ TUNEL-positive cells $/ 10^{3}$ cells } \\
\hline (TUNEL index) & $38 \pm 2$ & $34 \pm 3$ & 89.4 & $18 \pm 2$ & $16 \pm 1$ & 88.9 \\
\hline
\end{tabular}

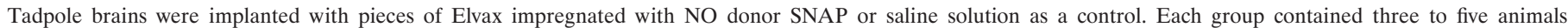

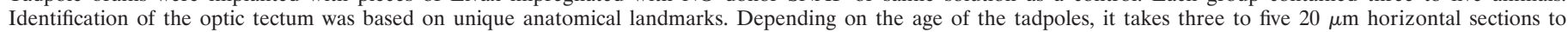

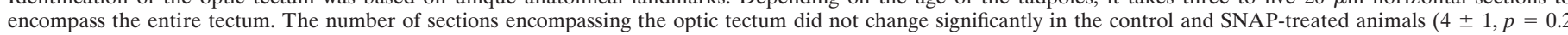

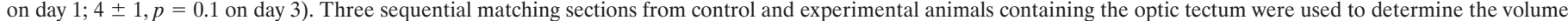

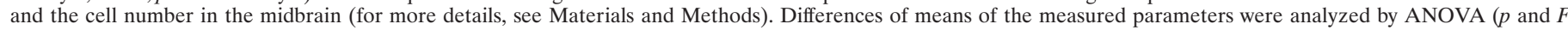

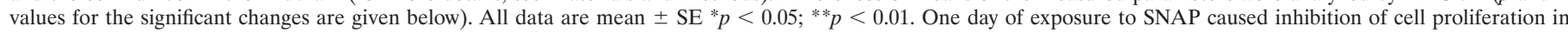

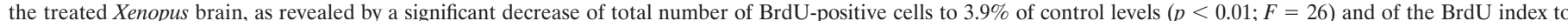

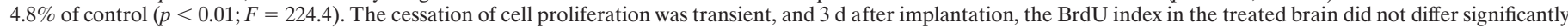

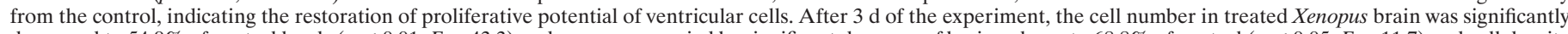

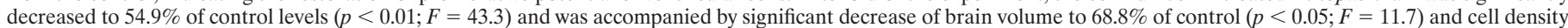

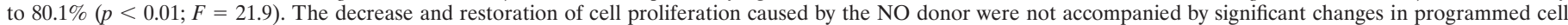
death as determined by TUNEL index.

proliferation by the $3 \mathrm{~d}$ time point indicates that the effect of SNAP on cell proliferation is reversible and that the concentration of SNAP used in these experiments was not toxic. This is corroborated by the results of the TUNEL assay (see below). The cell density, cell number, and midbrain volume were significantly reduced after $3 \mathrm{~d}$ of SNAP treatment (Fig. 3, Table 1). Although an increase in programmed cell death in response to NO could, in principle, contribute to these effects, including both the decrease in the total number of cells in the midbrain and the decrease in midbrain volume, we observed no significant change in the relative number of TUNEL-positive cells (TUNEL index) in SNAPtreated brains.

\section{NOS inhibitors distort brain morphogenesis}

The close proximity of proliferating and NOS-expressing cells in the optic tectum and data from the NO donor experiments above 

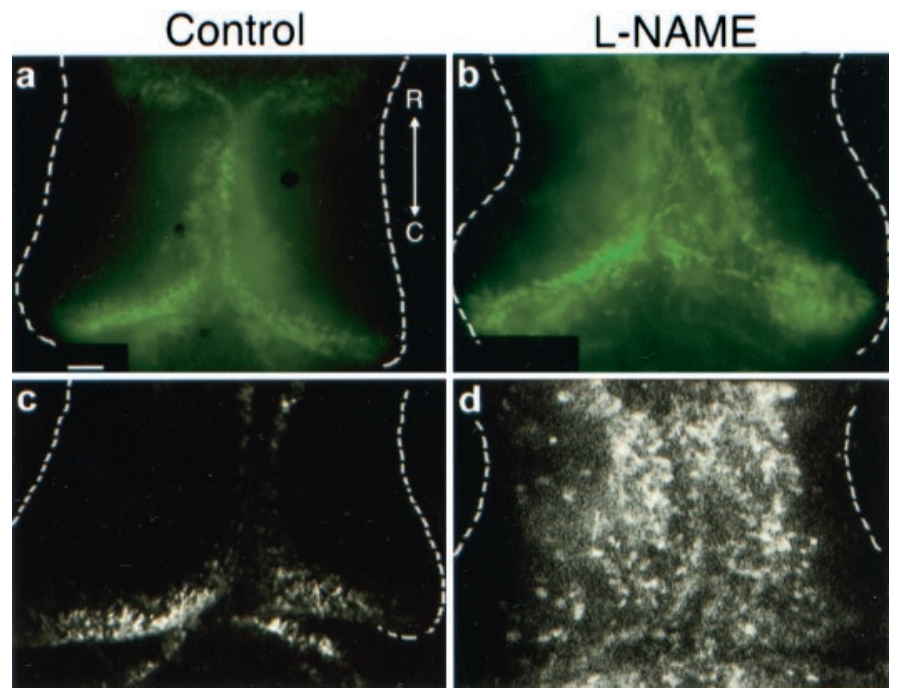

Figure 4. NOS inhibitors increase cell proliferation in the optic tectum. Animals were treated with Elvax impregnated with the NOS inhibitor L-NAME or saline as a control. Three days later, dividing cells were labeled by BrdU incorporation for $2 \mathrm{hr}$. The distribution of BrdU-labeled cells is shown for two pairs of animals as whole-mount images of the optic tectum photographed by fluorescent microscopy $(a, b)$ or as a projection of confocal optical sections through the tectum $(c, d)$. L-NAME increases the number of cells labeled by BrdU incorporation and causes an expansion of BrdU-labeled cells outside on the normal proliferative zone. Dotted lines mark the midbrain. Rostral $(R)$ is at the top; $C$, caudal. Scale bar, $50 \mu \mathrm{m}$.

are consistent with the proposed antiproliferative role of NO during Xenopus brain development. To test the causative role of $\mathrm{NO}$ in cell cycle arrest of neuronal precursors and to determine whether production of NO is necessary for cell cycle arrest and subsequent differentiation of neuronal precursors in the developing Xenopus brain, we inhibited NOS activity in the brain by using Elvax matrix impregnated with an NOS inhibitor, either L-NAME or ETU, or with saline as a control. Pieces of impregnated matrix were inserted into the brain ventricle of stage 45 tadpoles. After 3 and $7 \mathrm{~d}$ of treatment, the brains were examined for changes in the patterns of cell division and differentiation, cell number, and overall size and morphology.

Both L-NAME and ETU significantly increased the total and the relative numbers of proliferating cells (BrdU index) in the brains of experimental animals in comparison with the brains of control animals. This was observed both at 3 and $7 \mathrm{~d}$ after the onset of drug treatment (Fig. 4, Table 2). Figure 4 shows two examples each of control and L-NAME-treated brains photographed as whole-mount preparations by traditional fluorescence microscopy and by confocal microscopy. In both examples, the numbers and distributions of BrdU-labeled cells are increased in L-NAME-treated animals. In contrast to the distribution of BrdU-positive cells in control brains, which is confined to a narrow band of cells within the proliferative zone in the caudomedial tectum, BrdU-labeled cells in L-NAME-treated animals were distributed throughout the optic tectal lobe. This is most clearly seen in projections of confocal images collected through the dorsal optic tectum (Fig. $4 c, d$ ), which show a wide area of BrdU-positive cells in L-NAME-treated animals extending rostrally and laterally in the tectum, in the normally cell-sparse neuropil region. L-NAME increased the relative number of BrdU-positive cells (BrdU index) to $262 \%$ of the control level at $3 \mathrm{~d}$ after treatment (Table 2). This increase was maintained at
$182 \%$ of the control values at $7 \mathrm{~d}$ of treatment. Similarly, ETU, a structurally different inhibitor of NOS, increased the BrdU index to $247 \%$ of the control value at $7 \mathrm{~d}$ of treatment.

To assess whether the surplus of dividing cells in animals treated with NOS inhibitors increased the number of cells in the midbrain, we stained sections with DAPI to reveal the cell nuclei. In control brains, cells in the optic tectum occupy a crescent extending along the medial and caudal edges of the tectal lobe (Fig. 5a). Only a few scattered cell bodies are located within the neuropil region, where input axons mingle with tectal cell dendrites. Midbrains of animals treated with NOS inhibitors have significantly more DAPI-stained cells than midbrains of control animals (Figs. $5 b-d, 6 a, b$; Table 2). L-NAME-treated brains have more cells than controls at 3 and $7 \mathrm{~d}$ (141 and 164\% of the control values, respectively), and ETU-treated brains have $154 \%$ of the control cell value at $7 \mathrm{~d}$ of treatment. These data suggest that the surplus cells in the $\mathrm{S}$ phase successfully completed the cell cycle by division and contributed to an increase in cell number in the brain. Extra cells distorted the lamination pattern in the optic tectum, formed ectopic islands, and filled the tectal neuropil.

A decrease in programmed cell death may contribute to the increase in cell numbers after treatment with NOS inhibitors. We assayed the number of apoptotic cells with the TUNEL assay to test the effect of inhibition of NOS on programmed cell death in the developing tadpole brain. Figure 6 shows adjacent sections of the optic tectum of animals treated for $3 \mathrm{~d}$ with Elvax impregnated with saline solution or with the NOS inhibitor L-NAME stained with DAPI to reveal the total number and distribution of cells (top row) labeled with BrdU to reveal proliferating cells (middle row) and assayed by TUNEL to reveal apoptotic cells (bottom row). Although the BrdU index and the total number of DAPI-stained nuclei significantly increased after a $3 \mathrm{~d}$ exposure to L-NAME, there was no corresponding change in the relative number (TUNEL index) or distribution of TUNEL-positive apoptotic cells (Fig. 6, Table 2). This demonstrates that programmed cell death did not significantly contribute to the increase in the total cell number after NOS inhibition.

To test whether the increased number of cells affects the size of the tadpole brain, we determined the volume of the dorsal midbrain and the cell density in control brains and in brains after inhibition of NOS (Table 2). Both L-NAME and ETU significantly increased cell density in the midbrain after $7 \mathrm{~d}$ of treatment to 152 and $125 \%$ of the control values, respectively. Treatment with ETU for $7 \mathrm{~d}$ also resulted in a significant increase of the midbrain volume (124\% of the control value; Table 2$)$.

We conducted an additional series of experiments designed to test the effect of D-NAME, the biologically inactive enantiomer of L-NAME, on cell proliferation in the tectum. Table 3 shows pairwise comparisons of the major parameters of cell proliferation and cell density after exposure to saline versus D-NAME, L-NAME versus saline or D-NAME, and ETU versus saline or D-NAME. These results show that although there were no statistically significant differences between changes evoked by saline and D-NAME, there were highly significant differences between the action of both L-NAME and ETU compared with either saline or D-NAME. The results presented in Table 3 are in very good agreement with the results presented in Table 2 and Figures $4-6$, and both confirm and extend the conclusions about the specificity of the effect of NOS inhibition on cell proliferation in the developing tadpole brain. 
Table 2. NOS inhibitors increase cell number, brain volume, and cell density in the tadpole brain

\begin{tabular}{|c|c|c|c|c|c|c|c|c|}
\hline & Control, $3 \mathrm{~d}$ & L-NAME, $3 \mathrm{~d}$ & $\begin{array}{l}\text { Change } \\
\text { (\% of control) }\end{array}$ & Control, $7 \mathrm{~d}$ & L-NAME, $7 \mathrm{~d}$ & $\begin{array}{l}\text { Change } \\
\text { (\% of control) }\end{array}$ & ETU, $7 \mathrm{~d}$ & $\begin{array}{l}\text { Change } \\
\text { (\% of control) }\end{array}$ \\
\hline Cell number & $3644 \pm 158$ & $5136 \pm 339^{*}$ & 140.9 & $8373 \pm 928$ & $13742 \pm 510^{*}$ & 164.1 & $12870 \pm 690^{*}$ & 153.7 \\
\hline Volume $\left(\mathrm{mm}^{3} \times 10^{-4}\right)$ & $52.7 \pm 3.8$ & $67.8 \pm 9.1$ & 128.7 & $99.4 \pm 4.9$ & $107.0 \pm 3.7$ & 107.6 & $123.0 \pm 4.3^{*}$ & 123.7 \\
\hline $\begin{array}{l}\text { Cell density } \\
\quad\left(\text { cells } / \mathrm{mm}^{3} \times 10^{-4}\right)\end{array}$ & $69 \pm 7$ & $76 \pm 11$ & 110.1 & $84 \pm 6$ & $128 \pm 10^{*}$ & 152.4 & $105 \pm 3^{*}$ & 125.0 \\
\hline $\begin{array}{l}\text { BrdU-positive cells } \\
\quad \text { (total) }\end{array}$ & $133 \pm 13$ & $499 \pm 40^{* *}$ & 375.2 & $141 \pm 10$ & $424 \pm 40^{*}$ & 300.7 & $537 \pm 25^{*}$ & 380.9 \\
\hline $\begin{array}{l}\text { BrdU-positive cells } / 10^{3} \\
\text { cells (BrdU index) }\end{array}$ & $37 \pm 3$ & $97 \pm 5^{* *}$ & 262.1 & $17 \pm 2$ & $31 \pm 3^{*}$ & 182.4 & $42 \pm 3^{*}$ & 247.1 \\
\hline $\begin{array}{l}\text { TUNEL-positive cells } \\
\text { (total) } \\
\text { TUNEL-positive } \\
\text { cells } / 10^{3} \text { cells } \\
\text { (TUNEL index) }\end{array}$ & $115 \pm 7$ & $168 \pm 16^{* *}$ & 146.1 & $83 \pm 8$ & $123 \pm 12^{*}$ & 148.2 & $179 \pm 25^{*}$ & 215.7 \\
\hline
\end{tabular}

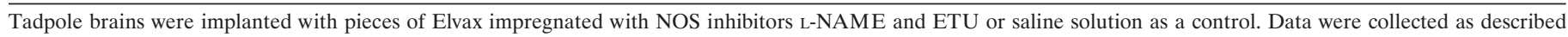

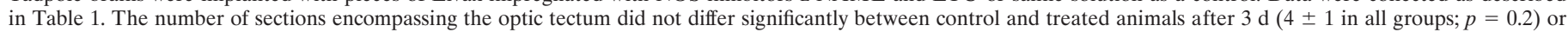

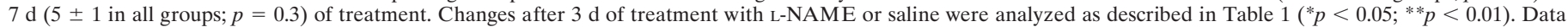

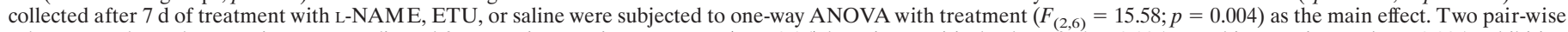

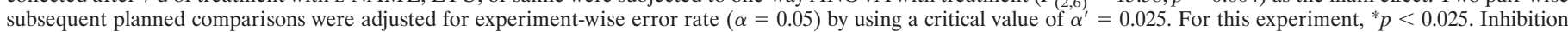

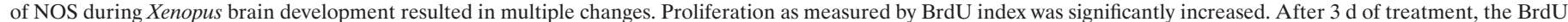

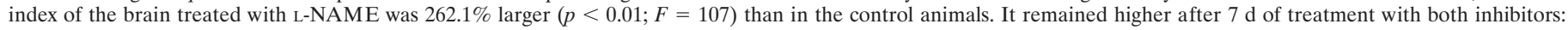

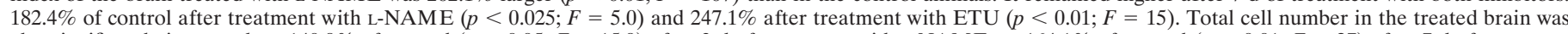

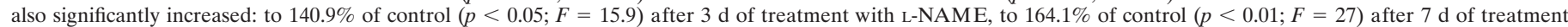

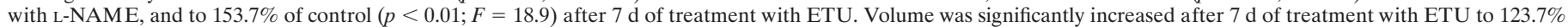

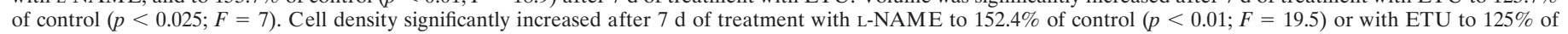

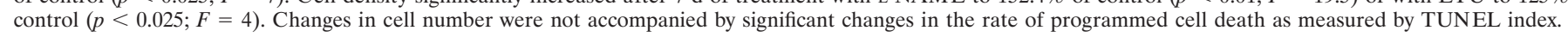
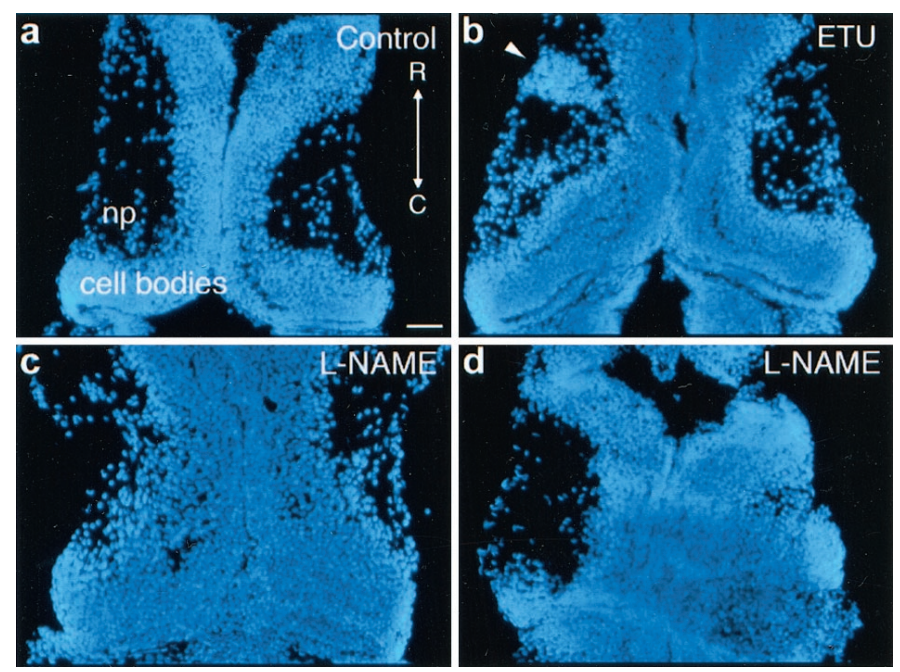

Figure 5. Inhibition of NOS increases cell number and distorts lamination in the developing brain. Compared with brains of control animals treated with saline $(a)$, DAPI staining of horizontal sections through the optic tectum reveals a larger number of nuclei in the cell body layer and disruption of the cellular distribution in the brains of animals treated with ETU $(b)$ or L-NAME $(c, d)$. In some cases, such as the example shown in $b$, clusters of extra cells formed ectopic islands (arrowhead) within the tectal neuropil, which normally contains densely packed processes. In the majority of cases, ectopic cells occupied the lateral tectum and filled the tectal neuropil $(c, d)$. Tectal neuropil $(n p)$ and cell body layer are labeled in the control image $(a)$. Rostral $(R)$ is at the top; $C$, caudal. Scale bar, $50 \mu \mathrm{m}$.

\section{Effect of NOS inhibitor on neuronal differentiation}

To determine whether the excess cells generated as a result of NOS inhibition are able to differentiate and express neuronal markers, we labeled brain sections with the pan-neuronal markers N-tubulin and N-CAM (Fig. 7 $a-d$ ). In both control and L-NAME- treated brains, N-tubulin and N-CAM immunoreactivity labeled differentiated tectal cell bodies and was concentrated in the tectal neuropil, consistent with their distribution in neuronal processes. Importantly, the staining patterns suggest that surplus cells in L-NAME-treated brains differentiate and express neuronal antigens. Both N-tubulin and N-CAM staining patterns also demonstrate the distortion of brain morphogenesis and tectal cell lamination, shown by DAPI staining in Figure 5 . The cell body region of the treated brains appears thicker. In addition, the greatly disorganized neuropil was more loosely and chaotically packed with processes, and the border between the neuropil and the cell body region was markedly irregular.

Antibodies to Islet-1 stain a subset of ventral motoneurons in chick, which are committed very early during vertebrate brain development (Ericson et al., 1992). Coronal brain sections through the rostrocaudal extent of the brain indicate that NOS inhibition did not affect the number or distribution of Islet-1expressing cells, although the increase in the size of the brain attributable to exposure to the NOS inhibitor was apparent (Fig. $7 e, f)$. This is consistent with the early differentiation of these neurons occurring before the inhibitors were applied at stage 45 . These data provide added support that the effects of NOS inhibitors on cell proliferation are specific. In addition, they suggest that NOS inhibition can influence the development of cells in the brain within a specific window of their development as they exit the cell cycle and begin to differentiate.

\section{DISCUSSION}

The Xenopus brain grows throughout larval development in a consistent pattern: new precursor cells are produced in discrete germinal zones of the brain; they stop dividing and are displaced laterally and rostrally from the germinal zone; and the cells differentiate and establish functional connections with other cells. Studies of mouse, chick, and frog development have revealed a 
Figure 6. NOS inhibition does not increase apoptosis. Animals treated for $3 \mathrm{~d}$ with saline solution $(a, c, e)$ or the NOS inhibitor L-NAME $(b, d, f)$ were injected with BrdU. Two hours later, the animals were killed, and alternating horizontal brain sections were stained with DAPI to stain nuclei $(a, b)$, with $\operatorname{BrdU}$ antibodies to label proliferating cells $(c, d)$, and with TUNEL to label apoptotic cells $(e, f)$. Although inhibition of NOS activity significantly increased the number of BrdUincorporating cells and the total number of cells in the midbrain, TUNEL-positive cells were not changed. Note that single horizontal sections only show a fraction of the BrdU-positive cells seen in wholemount sections (Fig. 4). The histograms on the right depict quantitative changes induced by NOS inhibitors, which are presented in more detail in Table 2. $n p$, Neuropil; $R$, rostral; $C$, caudal. * $p<0.05 ;{ }^{* *} p<$ 0.01. Scale bar, $50 \mu \mathrm{m}$.
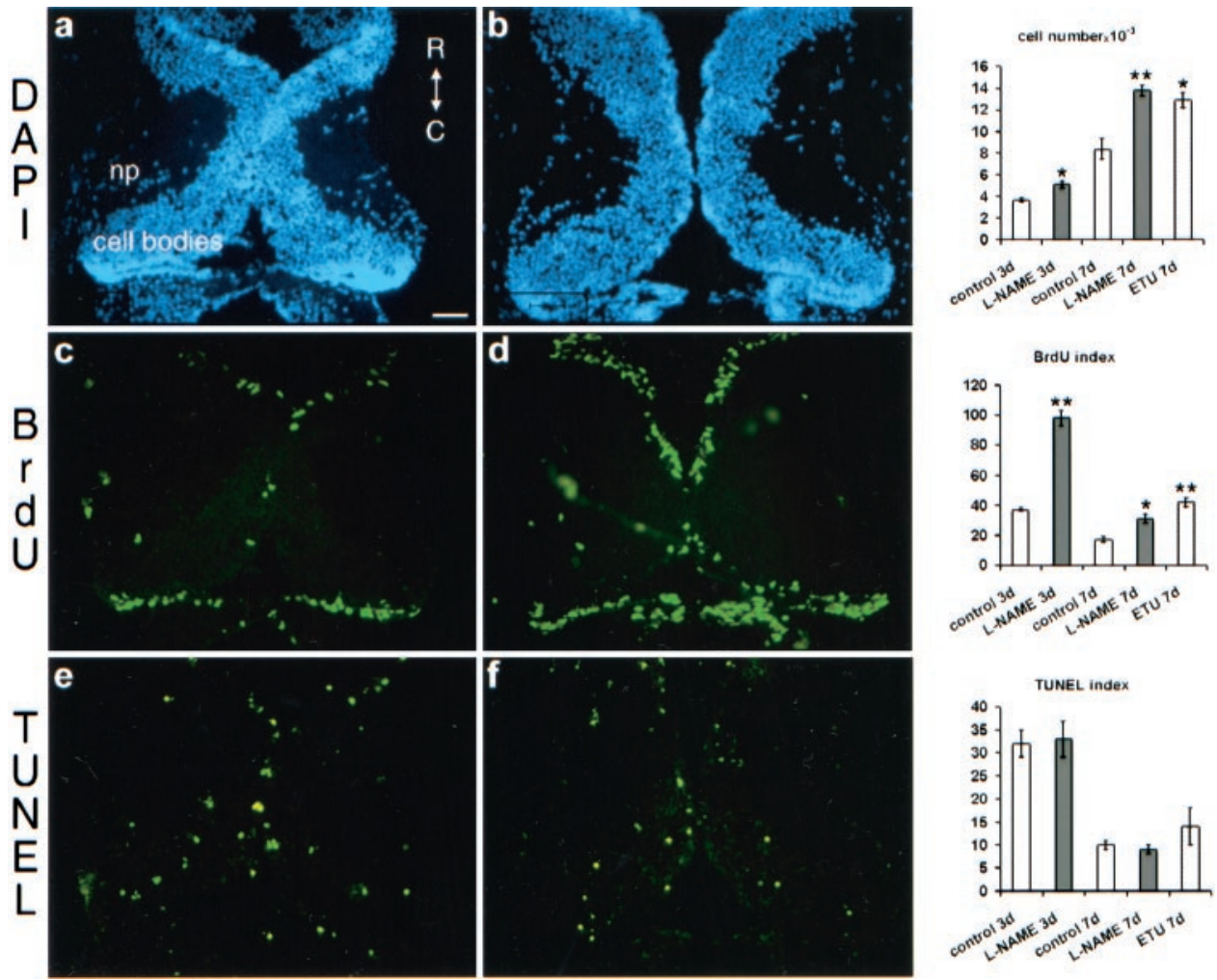

Table 3. NOS inhibitors, but not inactive enantiomer, increase cell number, brain volume, and cell density in the tadpole brain

\begin{tabular}{|c|c|c|c|c|c|c|c|}
\hline & PBS & D-NAME & $\begin{array}{l}\text { Change, } \\
\text { D-NAME } \\
(\% \text { of PBS) }\end{array}$ & L-NAME & $\begin{array}{l}\text { Change, } \\
\text { L-NAME } \\
\text { (\% of D-NAME) }\end{array}$ & ETU & $\begin{array}{l}\text { Change, ETU } \\
(\% \text { of D-NAME) }\end{array}$ \\
\hline Cell number & $7138 \pm 490$ & $7742 \pm 584$ & 109 & $10396 \pm 806$ & $134^{*}$ & $8639 \pm 279$ & 112 \\
\hline Brain volume $\left(\mathrm{mm}^{3} \times 10^{-4}\right)$ & $107 \pm 3$ & $102 \pm 6$ & 95 & $115.5 \pm 9$ & 113 & $91 \pm 4$ & 99 \\
\hline Cell density $\left(\right.$ cells $\left./ \mathrm{mm}^{3} \times 10^{-4}\right)$ & $66.7 \pm 5$ & $76 \pm 3$ & 114 & $90 \pm 9$ & 118 & $95 \pm 2$ & $125^{*}$ \\
\hline BrdU-positive cells (total) & $152 \pm 36$ & $133 \pm 16$ & 88 & $441 \pm 26$ & $332 *$ & $334 \pm 10$ & $251^{*}$ \\
\hline $\begin{array}{l}\text { BrdU-positive cells } / 10^{3} \text { cells } \\
\quad \text { (BrdU index) }\end{array}$ & $21 \pm 3$ & $17 \pm 1$ & 81 & $42 \pm 3$ & $247^{*}$ & $39 \pm 3$ & $229^{*}$ \\
\hline
\end{tabular}

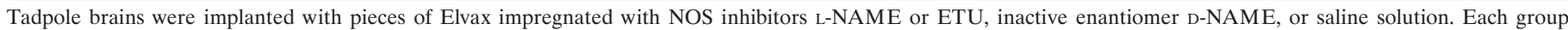

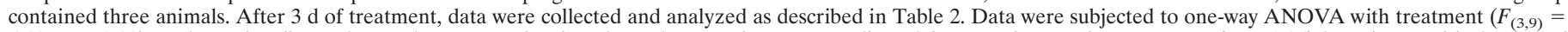

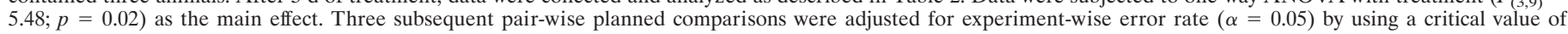

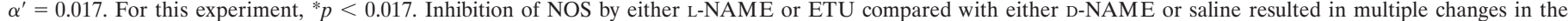

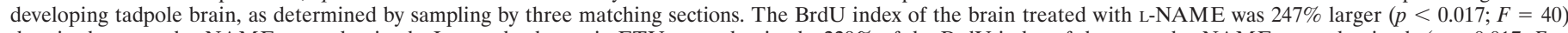

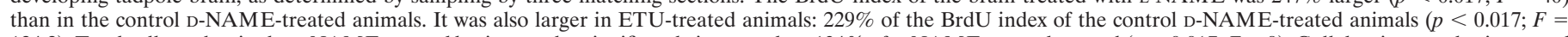

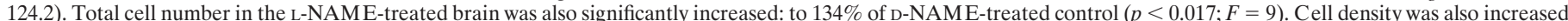

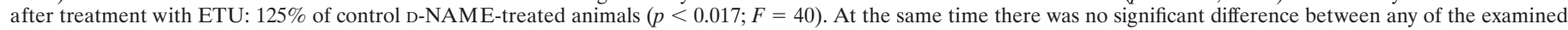
parameters in D-NAME- or saline-treated animals.

number of growth and transcription factors that determine the patterning of the developing vertebrate brain; however, the mechanisms that determine how precursor cells coordinately cease proliferating and differentiate are still unknown.

Here we show that NOS activity regulates cell number in the developing brain of the tadpole. NOS inhibition results in excess cell division, an increase in the total number of cells in the developing brain, an increase in the size of the brain, and a profound distortion of the overall cellular organization of the brain. Conversely, increased levels of NO have a reciprocal effect: reduced cell division, a decrease in the total number of cells, and a decreased brain size. The observed changes in cell number can be attributed to changed proliferation. Together, these data indicate that NO acts as an essential antiproliferative factor.
In addition, our results demonstrate that the pool of precursor cells capable of differentiating into mature cells of the optic tectum can undergo additional cycles of division in the absence of NO, thus suggesting that their capacity to continue dividing is not predetermined.

In the optic tectum of Xenopus, NO may act downstream of growth factors such as NGF and BDNF to regulate cell proliferation during development of the visual system (Cohen-Cory and Fraser, 1994), because considerable evidence indicates that many of the pleiotropic effects of growth factors are mediated through NO (Peunova and Enikolopov, 1995; Hikiji et al., 1997; K. H. Lee et al., 1997; Obregon et al., 1997; Papapetroupoulos et al., 1997a,b; Poluha et al., 1997; Babaei et al., 1998; Cote et al., 1998; Kim et al., 1998; Nisoli et al., 1998; Phung et al., 1999; Nakagawa 
Control
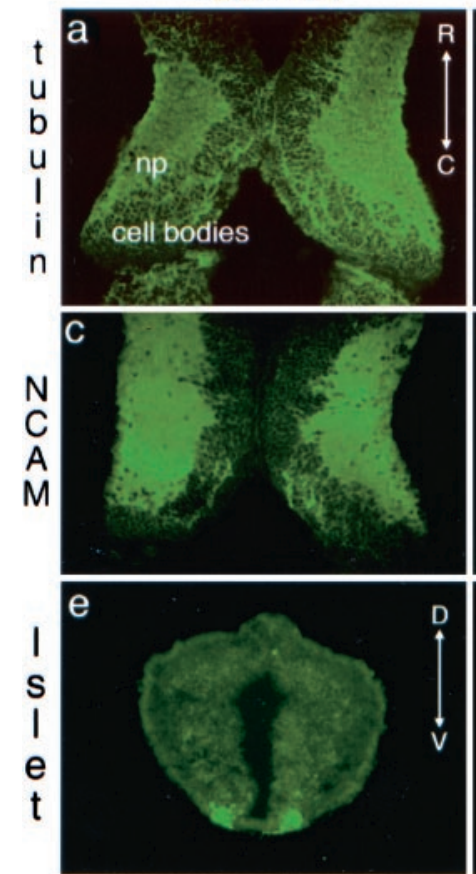
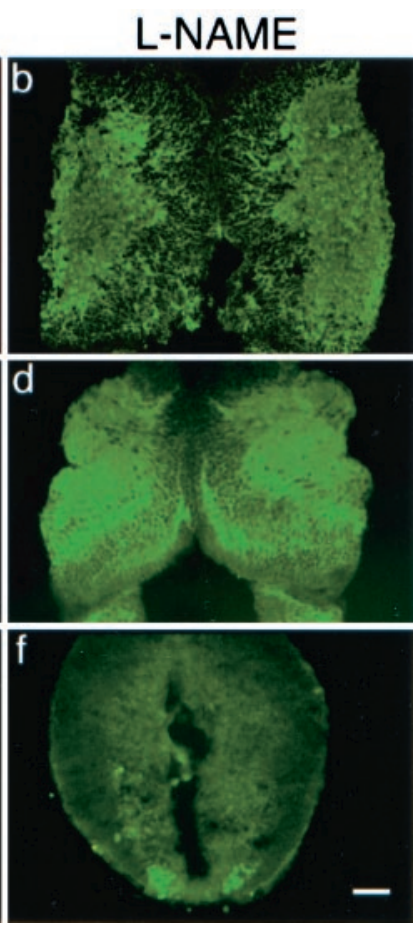

Figure 7. Selective effect of NOS inhibition on neuronal differentiation. $a-d$, Horizontal brain sections of animals treated with saline (Control) and L-NAME for $7 \mathrm{~d}$ were immunostained with antibodies to panneuronal markers N-tubulin $(a, b)$ and N-CAM $(c, d)$. Excess cells generated as a result of NOS inhibition differentiate and express neuronal markers. Note the gross disorganization of the optic tectum in animals treated with the NOS inhibitor L-NAME. $e, f$, Coronal brain sections through the brains of animals treated with saline (Control) or L-NAME in Elvax were immunostained with antibodies to Islet-1. Islet 1-positive neurons differentiated before L-NAME treatment was started. Although the overall sizes of the brains of L-NAME-treated animals were larger, and they contained more cells, the pattern and number of the early differentiating Islet-1-positive neurons were not affected by L-NAME treatment, as shown in the representative sections. Rostral $(R)$ is at the top in $a-d$; $C$, caudal; dorsal $(D)$ is at the top in $e, f ; V$, ventral. Scale bar, $50 \mu \mathrm{m}$.

et al., 2000). The molecular mechanisms by which NO inhibits cell proliferation are poorly characterized. NO is a highly reactive molecule, which may interact with and modify a number of potential targets. In addition to guanylate cyclase and ribonucleotide reductase (Garg and Hassid, 1989; Lepoivre et al., 1990; Kwon et al., 1991; Bredt and Snyder, 1994b; Nathan and Xie, 1994; Wingrove and O'Farrell, 1999), two direct targets of NO, the genes and proteins that mediate the antiproliferative activity of NO may include the components of the retinoblastoma $(\mathrm{Rb})$ pathway such as p21 (Poluha et al., 1997), cell cycle-dependent kinases (Ishida et al., 1997), or Rb and E2F (Kuzin et al., 2000; Jaffrey et al., 2001).

NO can affect both the cell in which it is produced and its neighbors. Indeed, the distribution of NOS-positive neurons relative to the tectal germinal zone is compatible with NO acting either in an autocrine or in a paracrine manner. NO may induce cell cycle arrest in proliferating cells within a zone of its diffusion after being produced by nearby sources such as the newly differentiated tectal neurons. These data support a model of brain morphogenesis in which the transcellular messenger NO coordinates the switch from proliferation to differentiation within groups of cells to create the complex anatomy of the brain.
An increasing number of developmental systems provide evidence that the ability of NO to prevent DNA synthesis and cell division is exploited as a part of a developmental program in a variety of tissues. NO synthesis is essential for the transition from cell proliferation to cell cycle arrest during organ development in fruit fly (Kuzin et al., 1996; Peunova et al., 1996; Kuzin et al., 2000), ecdysone-induced neurogenesis in the optic lobe in moth (Champlin and Truman, 2000), hematopoiesis in mouse (T. Michurina, P. Krasnov, and G. Enikolopov, unpublished results), and brain development in frog (this study). In addition, NO is crucial for the differentiation of cultured neuronal cells (Peunova and Enikolopov, 1995; Obregon et al., 1997; Poluha et al., 1997; Cote et al., 1998; Phung et al., 1999; Nakagawa et al., 2000), endothelial cells (Papapetroupoulos et al., 1997a,b; Babaei et al., 1998), adipocytes (Nisoli et al., 1998), osteoblasts (Hikiji et al., 1997), myoblasts (K. H. Lee et al., 1997; Kim et al., 1998), and cardiomyocytes (Bloch et al., 1999).

NO may also be important for the control of cell division in the developing and adult mammalian brain. However, the effects of NO on neurogenesis have not yet been established using NOS mutant mice. In addition, attempts to probe the role of NO in mammalian brain morphogenesis are complicated by the unusual complexity of NOS genes: in particular, the use of alternative promoters and splice sites leads to the generation of multiple nNOS RNA and protein isoforms (Brenman et al., 1997; Eliasson et al., 1997; M. A. Lee et al., 1997; Wang et al., 1999), and some of these isoforms may compensate for the genetic defects in nNOS mutants (Huang et al., 1993; Brenman et al., 1996). It will be important to examine the role of $\mathrm{NO}$ in mammalian brain development by performing rigorous quantitative analysis of neurogenesis in NOS-null mutant mice.

Interestingly, we have observed a transient elevation of NOS expression in various tissues and organs of the developing Xenopus tadpole in addition to the brain (Peunova, unpublished observations). Blood vessels, muscles, skin, heart, and kidney of developing Xenopus express NOS during organogenesis, suggesting that NO may play an antiproliferative role during development of these tissues as well. Indeed, NOS levels are transiently increased during the development of many tissues and organs in mammals, where this transient elevation often coincides with the cessation of division of committed precursor cells (Bredt and Snyder, 1994a; Blottner et al., 1995; Collin-Osdoby et al., 1995; Shaul, 1995; Wetts et al., 1995). In addition, NOS activity is greatly elevated in regenerating tissues (Collin-Osdoby et al., 1995; Hortelano et al., 1995; Bruch-Gerharz et al., 1998; Poppa et al., 1998). Together, studies of various tissues and cell types, including the brain, suggest that NO may regulate morphogenesis by acting as an endogenous negative regulator of cell proliferation.

\section{REFERENCES}

Babaei S, Teichert-Kuliszewska K, Monge JC, Mohamed F, Bendeck MP Stewart DJ (1998) Role of nitric oxide in the angiogenic response in vitro to basic fibroblast growth factor. Circ Res 82:1007-1015.

Bloch W, Fleischmann BK, Lorke DE, Andressen C, Hops B, Hescheler J, Addicks K (1999) Nitric oxide synthase expression and role during cardiomyogenesis. Cardiovasc Res 43:675-684.

Blottner D, Grozdanovic Z, Gossrau R (1995) Histochemistry of nitric oxide synthase in the nervous system. Histochem J 27:785-811.

Bredt DS, Snyder SH (1994a) Transient nitric oxide synthase neurons in embryonic cerebral cortical plate, sensory ganglia, and olfactory epithelium. Neuron 13:301-313.

Bredt DS, Snyder SH (1994b) Nitric oxide: a physiologic messenger molecule. Annu Rev Biochem 63:175-195.

Brenman JE, Chao DS, Xia H, Aldape K, Bredt DS (1995) Nitric oxide 
synthase complexed with dystrophin and absent from skeletal muscle sarcolemma in Duchenne muscular dystrophy. Cell 82:743-752.

Brenman JE, Chao DS, Gee SH, McGee AW, Craven SE, Santillano DR, Wu Z, Huang F, Xia H, Peters MF, Froehner SC, Bredt DS (1996) Interaction of nitric oxide synthase with the postsynaptic density protein PSD-95 and alpha1-syntrophin mediated by PDZ domains. Cell 84:757-767.

Brenman JE, Xia H, Chao DS, Black SM, Bredt DS (1997) Regulation of neuronal nitric oxide synthase through alternative transcripts. Dev Neurosci 19:224-231.

Bruch-Gerharz D, Ruzicka T, Kolb-Bachofen V (1998) Nitric oxide and its implications in skin homeostasis and disease: a review. Arch Dermatol Res 290:643-651.

Champlin DT, Truman JW (2000) Ecdysteroid coordinates optic lobe neurogenesis via a nitric oxide signaling pathway. Development 127:3543-3551.

Cline HT, Constantine-Paton M (1989) NMDA receptor antagonists disrupt the retinotectal topographic map. Neuron 3:413-426.

Cline HT, Debski EA, Constantine-Paton M (1987) N-methyl-D-aspartate receptor antagonist desegregates eye-specific stripes. Proc Natl Acad Sci USA 84:4342-4345.

Coggeshall RE (1992) A consideration of neural counting methods. Trends Neurosci 15:9-13.

Cohen-Cory S, Fraser SE (1994) BDNF in the development of the visual system of Xenopus. Neuron 12:747-761.

Collin-Osdoby P, Nickols GA, Osdoby P (1995) Bone cell function, regulation, and communication: a role for nitric oxide. J Cell Biochem 57:399-408.

Cote F, Laflamme L, Payet MD, Gallo-Payet N (1998) Nitric oxide, a new second messenger involved in the action of angiotensin II on neuronal differentiation of NG108-15 cells. Endocr Res 24:403-407.

Eliasson MJ, Blackshaw S, Schell MJ, Snyder SH (1997) Neuronal nitric oxide synthase alternatively spliced forms: prominent functional localizations in the brain. Proc Natl Acad Sci USA 94:3396-3401.

Enikolopov G, Banerji J, Kuzin B (1999) Nitric oxide and Drosophila development. Cell Death Differ 6:956-963.

Ericson J, Thor S, Edlund T, Jessell TM, Yamada T (1992) Early stages of motor neuron differentiation revealed by expression of homeobox gene Islet-1. Science 256:1555-1560.

Garg UC, Hassid A (1989) Nitric oxide-generating vasodilators and 8-bromo-cyclic guanosine monophosphate inhibit mitogenesis and proliferation of cultured rat vascular smooth muscle cells. J Clin Invest $83: 1774-1777$

Harlow E, Lane D (1990) Antibodies: a laboratory manual. Cold Spring Harbor, NY: Cold Spring Harbor Laboratory.

Hemmati-Brivanlou A, Frank D, Bolce ME, Brown BD, Sive HL, Harland RM (1990) Localization of specific mRNAs in Xenopus embryos by whole-mount in situ hybridization. Development 110:325-330.

Hikiji H, Shin WS, Oida S, Takato T, Koizumi T, Toyo-oka T (1997) Direct action of nitric oxide on osteoblastic differentiation. FEBS Lett 410:238-242.

Hortelano S, Dewez B, Genaro AM, Diaz-Guerra MJ, Bosca L (1995) Nitric oxide is released in regenerating liver after partial hepatectomy. Hepatology 21:776-786.

Huang PL, Dawson TM, Bredt DS, Snyder SH, Fishman MC (1993) Targeted disruption of the neuronal nitric oxide synthase gene. Cell 75:1273-1286.

Ignarro L, Murad F, eds (1995) Nitric oxide: biochemistry, molecular biology, and therapeutic implications. New York: Academic.

Ishida A, Sasaguri T, Kosaka C, Nojima H, Ogata J (1997) Induction of the cyclin-dependent kinase inhibitor p21(Sdi1/Cip1/Waf1) by nitric oxide-generating vasodilator in vascular smooth muscle cells. J Biol Chem 272:10050-10057.

Jacobson M (1991) Developmental neurobiology. New York: Plenum.

Jaffrey SR, Snowman AM, Eliasson MJ, Cohen NA, Snyder SH (1998) CAPON: a protein associated with neuronal nitric oxide synthase that regulates its interactions with PSD95. Neuron 20:115-124.

Jaffrey SR, Erdjument-Bromage H, Ferris CD, Tempst P, Snyder SH (2001) Protein S-nitrosylation: a physiological signal for neuronal nitric oxide. Nat Cell Biol 3:193-197.

Kandel ER, Schwartz JH, Jessell TM (2000) Principles of neural science. New York: McGraw-Hill.

Kim SS, Rhee S, Lee KH, Kim JH, Kim HS, Kang MS, Chung CH (1998) Inhibitors of the proteasome block the myogenic differentiation of rat L6 myoblasts. FEBS Lett 433:47-50.

Kuzin B, Roberts I, Peunova N, Enikolopov G (1996) Nitric oxide regulates cell proliferation during Drosophila development. Cell 87:639-649.

Kuzin B, Regulski M, Stasiv Y, Scheinker V, Tully T, Enikolopov G (2000) Nitric oxide interacts with the retinoblastoma pathway to control eye development in Drosophila. Curr Biol 10:459-462.

Kwon NS, Stuehr DJ, Nathan CF (1991) Inhibition of tumor cell ribo- nucleotide reductase by macrophage-derived nitric oxide. J Exp Med 174:761-767.

Lazar G (1973) The development of the optic tectum in Xenopus laevis: a Golgi study. J Anat 116:347-355.

Lee KH, Kim DG, Shin NY, Song WK, Kwon H, Chung CH, Kang MS (1997) NF-kappaB-dependent expression of nitric oxide synthase is required for membrane fusion of chick embryonic myoblasts. Biochem J 324:237-242.

Lee MA, Cai L, Hubner N, Lee YA, Lindpaintner K (1997) Tissue- and development-specific expression of multiple alternatively spliced transcripts of rat neuronal nitric oxide synthase. $\mathrm{J}$ Clin Invest 100:1507-1512.

Lepoivre M, Chenais B, Yapo A, Lemaire G, Thelander L, Tenu JP (1990) Alterations of ribonucleotide reductase activity following induction of the nitrite-generating pathway in adenocarcinoma cells. J Biol Chem 265:14143-14149.

Moreno-Lopez B, Noval JA, Gonzalez-Bonet LG, Estrada C (2000) Morphological bases for a role of nitric oxide in adult neurogenesis. Brain Res 30:244-250.

Nakagawa H, Yoshida M, Miyamoto S (2000) Nitric oxide underlies the differentiation of PC12 cells induced by depolarization with high $\mathrm{KCl}$. J Biochem 127:113-119.

Nathan C, Xie QW (1994) Nitric oxide synthases: roles, tolls, and controls. Cell 78:915-918.

Nieuwkoop PD, Faber J (1994) Normal table of Xenopus laevis (Daudin). New York: Garland.

Nisoli E, Clementi E, Tonello C, Sciorati C, Briscini L, Carruba MO (1998) Effects of nitric oxide on proliferation and differentiation of rat brown adipocytes in primary cultures. Br J Pharmacol 125:888-894.

Obregon E, Punzon MC, Gonzalez-Nicolas J, Fernandez-Cruz E, Fresno M, Munoz-Fernandez MA (1997) Induction of adhesion/differentiation of human neuroblastoma cells by tumour necrosis factor-alpha requires the expression of an inducible nitric oxide synthase. Eur J Neurosci 9:1184-1193.

Papapetropoulos A, Desai KM, Rudic RD, Mayer B, Zhang R, RuizTorres MP, Garcia-Cardena G, Madri JA, Sessa WC (1997a) Nitric oxide synthase inhibitors attenuate transforming-growth-factor-beta 1-stimulated capillary organization in vitro. Am J Pathol 150:1835-1844.

Papapetropoulos A, Garcia-Cardena G, Madri JA, Sessa WC (1997b) Nitric oxide production contributes to the angiogenic properties of vascular endothelial growth factor in human endothelial cells. J Clin Invest 100:3131-3139.

Peunova N, Enikolopov G (1995) Nitric oxide triggers a switch to growth arrest during differentiation of neuronal cells. Nature 375:68-73.

Peunova N, Kuzin B, Roberts I, O'Kane C, Enikolopov G (1996) Nitric oxide, cell multiplication, and cell survival. Cold Spring Harb Symp Quant Biol 61:417-426.

Phung YT, Bekker JM, Hallmark OG, Black SM (1999) Both neuronal NO synthase and nitric oxide are required for PC12 cell differentiation: a cGMP independent pathway. Brain Res Mol Brain Res 64:165-178.

Poluha W, Schonhoff CM, Harrington KS, Lachyankar MB, Crosbie NE Bulseco DA, Ross AH (1997) A novel, nerve growth factor-activated pathway involving nitric oxide, $\mathrm{p} 53$, and $\mathrm{p} 21 \mathrm{WAF} 1$ regulates neuronal differentiation of PC12 cells. J Biol Chem 272:24002-24007.

Poppa V, Miyashiro JK, Corson MA, Berk BC (1998) Endothelial NO synthase is increased in regenerating endothelium after denuding in jury of the rat aorta. Arterioscler Thromb Vasc Biol 18:1312-1321.

Renteria RC, Constantine-Paton M (1999) Nitric oxide in the retinotectal system: a signal but not a retrograde messenger during map refinement and segregation. J Neurosci 19:7066-7076.

Schlaggar BL, Fox K, O'Leary DD (1993) Postsynaptic control of plasticity in developing somatosensory cortex. Nature 364:623-626.

Shaul PW (1995) Nitric oxide in the developing lung. Adv Pediatr 42:367-414

Stamler JS, Feelisch M, eds (1996) Methods in nitric oxide research. New York: Wiley.

Straznicky K, Gaze RM (1972) The development of the tectum in Xenopus laevis: an autoradiographic study. J Embryol Exp Morphol 28:87-115.

Wang Y, Marsden PA (1995) Nitric oxide synthases: gene structure and regulation. Adv Pharmacol 34:71-90.

Wang Y, Newton DC, Robb GB, Kau CL, Miller TL, Cheung AH, Hall AV, VanDamme S, Wilcox JN, Marsden PA (1999) RNA diversity has profound effects on the translation of neuronal nitric oxide synthase. Proc Natl Acad Sci USA 96:12150-12155.

Wetts R, Phelps PE, Vaughn JE (1995) Transient and continuous expression of NADPH diaphorase in different neuronal populations of developing rat spinal cord. Dev Dyn 202:215-228.

Wingrove JA, O'Farrell PH (1999) Nitric oxide contributes to behavioral, cellular, and developmental responses to low oxygen in Drosophila. Cell 98:105-114. 